\title{
A Second T-Region of the Soybean-Supervirulent Chrysopine-Type Ti Plasmid pTiChry5, and Construction of a Fully Disarmed vir Helper Plasmid
}

\author{
Karuppaiah Palanichelvam, ${ }^{1}$ Philippe Oger, ${ }^{1}$ Steven J. Clough, ${ }^{1}$ Chung Cha, ${ }^{1}$ \\ Andrew F. Bent, ${ }^{1}$ and Stephen K. Farrand ${ }^{1,2}$ \\ Departments of ${ }^{1} \mathrm{Crop}$ Sciences and ${ }^{2}$ Microbiology, University of Illinois at Urbana-Champaign, Urbana \\ 61801 , U.S.A. \\ Accepted 1 June 2000.
}

\begin{abstract}
Agrobacterium tumefaciens Chry5, which is particularly virulent on soybeans, induces tumors that produce a family of Amadori-type opines that includes deoxyfructosyl glutamine (Dfg) and its lactone, chrysopine (Chy). Cosmid clones mapping to the right of the known oncogenic Tregion of pTiChry5 conferred Amadori opine production on tumors induced by the nopaline strain C58. Sequence analysis of DNA held in common among these cosmids identified two 25-bp, direct repeats flanking an 8.5-kb segment of pTiChry5. These probable border sequences are closely related to those of other known T-regions and define a second T-region of pTiChry5, called T-right $\left(T_{R}\right)$, that confers production of the Amadori opines. The oncogenic T-left region $\left(T_{L}\right)$ was located precisely by identifying and sequencing the likely border repeats defining this segment. The two T-regions are separated by approximately $15 \mathrm{~kb}$ of plasmid DNA. Based on these results, we predicted that pKYRT1, a vir helper plasmid derived from pTiChry5, still contains all of $T_{R}$ and the leftmost $9 \mathrm{~kb}$ of $T_{L}$. Consistent with this hypothesis, transgenic Arabidopsis thaliana plants selected for with a marker encoded by a binary plasmid following transformation with KYRT1 coinherited production of the Amadori opines at high frequency. All opine-positive transgenic plants also contained $T_{R}$-DNA, while those plants that lacked $T_{R}-$ DNA failed to produce the opines. Moreover, $A$. thaliana infected with KYRT1 in which an nptII gene driven by the $35 \mathrm{~S}$ pro-
\end{abstract}

Corresponding author: Stephen K. Farrand, Department of Crop Sciences, University of Illinois at Urbana-Champaign, 240 ERML, 1201 West Gregory Drive, Urbana 61801, U.S.A.; Telephone: 1-217-333-1524; Fax: 1-217-244-7830; E-mail: stephenf@uiuc.edu

Current address of Karuppaiah Palanichelvam: Department of Plant Microbiology and Pathology, University of Missouri-Columbia, Columbia 65211, U.S.A.

Current address of Philippe Oger: Institut des Sciences Végétales, CNRS, 91198 Gif sur Yvette, France.

Current address of Andrew F. Bent: Department of Plant Pathology, University of Wisconsin, Madison 53706, U.S.A.

Nucleotide and/or amino acid sequence data have been deposited at the GenBank data base as accession nos. AF229155 and AF229156 for the right and left borders of $\mathrm{T}_{\mathrm{L}}$, respectively, and AF229157 for the left and right borders of $T_{R}$. moter of Cauliflower mosaic virus was inserted directly into the vir helper plasmid yielded kanamycin-resistant transformants at a low but detectable frequency. These results demonstrate that pKYRT1 is not disarmed, and can transfer Ti plasmid DNA to plants. A new vir helper plasmid was constructed from pTiChry5 by two rounds of sacB-mediated selection for deletion events. This plasmid, called pKPSF2, lacks both of the known T-regions and their borders. pKPSF2 failed to transfer Ti plasmid DNA to plants, but mobilized the T-region of a binary plasmid at an efficiency indistinguishable from those of pKYRT1 and the nopaline-type vir helper plasmid pMP90.

Additional keywords: binary system, disarmed plasmid, Glycine $\max$, T-DNA.

Agrobacterium tumefaciens, a phytopathogenic soil bacterium, causes crown gall disease on many dicotyledonous plants. Most of the traits responsible for pathogenesis are borne on a large, extrachromosomal element called the Ti (tumor-inducing) plasmid (Zupan and Zambryski 1995). Upon infection, a portion of the Ti plasmid, called the T-region, is transferred to the plant nucleus, where it can be stably integrated into chromosomal DNA. Functions involved in processing the T-region and transferring the resultant T-DNA to the plant cell are coded for by the vir region of the Ti plasmids (de la Cruz and Lanka 1998). Oncogenes on some T-DNAs encode enzymes for synthesis of indole acetic acid and cytokinins, the overproduction of which in the transformed plant cells is responsible for the tumorous phenotype (Binns and Costantino 1998). Other T-DNA genes encode biosynthetic pathways for novel, plant-produced compounds called opines. The opines, in turn, are taken up and specifically utilized by the bacteria that induced the tumors via catabolic systems coded for by genes also located on the Ti plasmid (Dessaux et al. 1998). On the Ti plasmids, the T-regions are delimited by 25-bp, imperfect, direct repeats called border sequences (Yadav et al 1982; Zambryski et al. 1982; Peralta and Ream 1985; Wang et al. 1984). Although some Ti plasmids contain a single T-region, others contain two such regions, each bounded by border sequences. In such cases each resulting T-DNA can be transferred independently to the plant cell nucleus during infection (Hooykaas and Schilperoort 1992). 
Agrobacterium tumefaciens and its Ti plasmids have proven useful for the directed genetic transformation of plants. Any foreign DNA can be transferred to the plant nucleus via the vir system provided the segment is flanked by T-region border repeats. Because the vir functions operate in trans, the Tregions and the vir genes need not be located on the same replicon (Hoekema et al. 1983; de Framond et al. 1983). Thus, experimentally, the vir functions often are provided by a nontumorigenic Ti plasmid derivative called a disarmed Ti plasmid or a vir helper plasmid, in which the native oncogenes and the T-region borders have been removed. Such vir helper plasmids have been constructed from several Ti plasmid types (Hood et al. 1986, 1993; Hoekema et al. 1983; Torisky et al. 1997; Zambryski et al. 1983). Genes to be transferred are contained on special binary vectors that code for two border repeats flanking a multiple cloning site, a plant-selectable marker, and other useful sequences (Jones et al. 1992).

Many isolates of Agrobacterium tumefaciens exhibit a broad host range. However, some plants, including soybean (Glycine $\max ($ L.) Merr.) are only poorly transformed by this bacterium. Although genes have been introduced into soybeans by several methods including microprojectile bombardment (McCabe et al. 1988), sonication-assisted Agrobacterium transformation (SAAT) (Trick and Finer 1997; Meurer et al. 1998) and Agrobacteriummediated DNA transfer (Hinchee et al. 1988; Chee et al. 1989; Di et al. 1996), the efficiency of these techniques remains poor. However, recent studies with Agrobacterium tumefaciens Chry5 has generated renewed interest in this bacterium as a gene delivery system. Chry5, which is hypervirulent on soybeans, harbors the chrysopine-type Ti plasmid pTiChry5 (Bush and Pueppke

Table 1. Bacterial strains and plasmids used in this study

\begin{tabular}{|c|c|c|}
\hline Strain or plasmid & Relevant characteristics & Reference \\
\hline \multicolumn{3}{|l|}{ Escherichia coli } \\
\hline DH5a & supE44 $\Delta$ lacU169 ( $\$ 80 l a c Z \Delta M 15)$ hsdR17 recA1 endA1 gyrA96 thi-1 relA-1 & Sambrook et al. 1989 \\
\hline S17-1 & Pro $^{-}$Res $^{-}$Mod $^{+}$recA; integrated RP4 Tc::Mu-Km::Tn 7, $\mathrm{Mob}^{+} ; \mathrm{Sm}^{\mathrm{r}}$ & Simon et al. 1983 \\
\hline \multicolumn{3}{|c|}{ Agrobacterium tumefaciens } \\
\hline Chry5 & Chrysopine-type strain, hypervirulent on soybean & Bush and Pueppke 1991 \\
\hline Chry5c & Ti plasmidless derivative of Chry5; Rif ${ }^{\mathrm{r}}$ & Kovacs and Pueppke 1993 \\
\hline C58 & Nopaline-type strain & Our collection \\
\hline NTL4 & $\mathrm{Tc}^{\mathrm{s}}$, Ti plasmidless derivative of strain C58 & Our collection \\
\hline GV3101 & Ti plasmidless derivative of strain C58, Rif $^{\mathrm{r}}$ & Holsters et al. 1980 \\
\hline LBA4404 & Ach5 harboring the vir helper plasmid pAL4404 & Hoekema et al. 1983 \\
\hline \multicolumn{3}{|l|}{ Plasmids } \\
\hline pUC19 & ColE1 cloning vector; $\mathrm{Ap}^{\mathrm{r}}$ & Sambrook et al. 1989 \\
\hline pSW213 & IncP cloning vector; $\mathrm{Tc}^{\mathrm{r}}$ & Chen and Winans 1991 \\
\hline pRK $415 \mathrm{~K}$ & Derivative of pRK415; IncP; $\mathrm{Km}^{\mathrm{r}}, \mathrm{Tc}^{\mathrm{r}}$ & Cook and Farrand 1992 \\
\hline pUM24 & Source of the $s a c B$-sacR-nptI cassette, $\mathrm{Km}^{\mathrm{r}}$ & Ried and Collmer 1987 \\
\hline pR29 & Source of the erythromycin resistance gene; $\mathrm{Em}^{\mathrm{r}}$ & Morrison et al. 1984 \\
\hline pBIN19 & Binary vector; $\mathrm{Km}^{\mathrm{r}}$ & Bevan 1984 \\
\hline pCaMVneo & $\begin{array}{l}\text { Binary vector, source of the plant selectable } n p t I I \text { driven by } 35 \mathrm{~S} \text { promoter of Cauliflower mosaic } \\
\text { virus (CaMV); } \mathrm{Km}^{\mathrm{r}}, \mathrm{Ap}^{\mathrm{r}}\end{array}$ & Fromm et al. 1986 \\
\hline pBINm-gfp5-ER & Binary vector with $g f p$ reporter gene; $\mathrm{Km}^{\mathrm{r}}$ & Haseloff et al. 1997 \\
\hline pBBRMCS-2 & Broad-host-range cloning vector; $\mathrm{Km}^{\mathrm{r}}$ & Kovach et al. 1995 \\
\hline pPH1JI & IncP; eviction plasmid; $\mathrm{Gm}^{\mathrm{r}}$ & Hirsch and Berenger 1984 \\
\hline $\mathrm{pCH} 3701$ & Cosmid clone of pTiChry5; coordinates $163.4-191.6$; contains the region to the left of TL-DNA; Tc ${ }^{r}$ & Kovacs and Pueppke 1994 \\
\hline $\mathrm{pCH} 230$ & Cosmid clone of pTiChry5; coordinates $184.2-7.6$; contains the entire $\mathrm{T}_{\mathrm{L}}-\mathrm{DNA} ; \mathrm{Tc}^{\mathrm{r}}$ & Kovacs and Pueppke 1994 \\
\hline pCH12 & Cosmid clone of pTiChry5; coordinates $186.0-18.6$; contains the entire $\mathrm{T}_{\mathrm{L}}-\mathrm{DNA} ; \mathrm{Tc}^{\mathrm{r}}$ & Kovacs and Pueppke 1994 \\
\hline pCH77 & Cosmid clone of pTiChry5; coordinates $195.4-22.6$; contains the entire $\mathrm{T}_{\mathrm{L}}$-DNA; $\mathrm{Tc}^{\mathrm{r}}$ & Kovacs and Pueppke 1994 \\
\hline $\mathrm{pCH} 235$ & Cosmid clone of pTiChry5; coordinates $5.8-33.7$; contains the e ntire $\mathrm{T}_{\mathrm{R}}$-DNA; $\mathrm{Tc}^{\mathrm{r}}$ & Kovacs and Pueppke 1994 \\
\hline pCH1755 & Cosmid clone of pTiChry5; coordinates $18.6-44.7$; contains part of $\mathrm{T}_{\mathrm{R}}-\mathrm{DNA}$; $\mathrm{Tc}^{\mathrm{r}}$ & Kovacs and Pueppke 1994 \\
\hline $\mathrm{pCH} 2546$ & Cosmid clone of pTiChry5; coordinates $38.2-63.3$; contains the region to the right of $\mathrm{T}_{\mathrm{R}} \mathrm{R}-\mathrm{DNA}$; $\mathrm{Tc}^{\mathrm{r}}$ & Kovacs and Pueppke 1994 \\
\hline pSWE9 & EcoRI fragment 9 of pTiChry5 in pSW213; $\mathrm{Tc}^{\mathrm{r}}$ & This study \\
\hline pSW9sac & $s a c B$-sacR-nptI cassette cloned in BamHI site of the insert in pSWE9; $\mathrm{Tc}^{\mathrm{r}}, \mathrm{Km}^{\mathrm{r}}$ & This study \\
\hline pUCE4 & EcoRI fragment 4 of pTiChry5 in pUC19; $\mathrm{Ap}^{\mathrm{r}}$ & This study \\
\hline pUCEd4 & pUCE4 deleted for $C l a I$ fragments internal to EcoRI fragment $4 ; \mathrm{Ap}^{\mathrm{r}}$ & This study \\
\hline pUCERd4 & $\mathrm{Em}^{\mathrm{r}}$ gene from pR29 cloned into the ClaI site of pUCEd4; $\mathrm{Ap}^{\mathrm{r}}, \mathrm{Em}^{\mathrm{r}}$ & This study \\
\hline pRKERd4 & EcoRI fragment from pUCERd4 cloned in pRK415K; $\mathrm{Km}^{\mathrm{r}}, \mathrm{Em}^{\mathrm{r}}$ & This study \\
\hline pPOC5E13 & EcoRI fragment 13 of pTiChry5 cloned in pUC19; $\mathrm{Ap}^{\mathrm{r}}$ & This study \\
\hline pPOC5E5 & EcoRI fragment 5 of pTiChry 5 cloned in ppBBRMCS-2; Km ${ }^{\mathrm{r}}$ & This study \\
\hline pPOC5B6 & BamHI fragment 6 of pTiChry5 cloned in pBBRMCS-2; $\mathrm{Km}^{\mathrm{r}}$ & This study \\
\hline pUCBE1 & Bam HI to EcoRI fragment from coordinates 168 to 178.3 of pTiChry5 in pUC19; Ap ${ }^{\mathrm{r}}$ & This study \\
\hline pUCBENP1 & $\begin{array}{l}\text { nptII driven by the CaMV } 35 \mathrm{~S} \text { promoter inserted into the HindIII site in the pTiChry5 insert of } \\
\text { pUCBE1; } \mathrm{Ap}^{\mathrm{r}}, \mathrm{Km}^{\mathrm{r}}\end{array}$ & This study \\
\hline $\mathrm{pMx} 230$ & sacB-sacR-nptI cassette marker-exchanged into EcoRI fragment 9 of pTiChry5; $\mathrm{Km}^{\mathrm{r}}$ & This study \\
\hline pMx106 & Erythromycin resistance gene marker-exchanged into EcoRI fragment 4 of pMx $230 \mathrm{Km}^{\mathrm{r}}, \mathrm{Em}^{\mathrm{r}}$ & This study \\
\hline pKPSF1 & $s a c B$-mediated deletion derivative of $\mathrm{pMx} 106: \mathrm{Em}^{\mathrm{r}}$ & This study \\
\hline pKPSF2 & $s a c B$-mediated deletion derivative of pKPSF1; vir helper plasmid; $\mathrm{Em}^{\mathrm{r}}$ & This study \\
\hline pKYRT1 & pTiChry5 deleted for $16.5 \mathrm{~kb}$ of DNA including most of $\mathrm{T}_{\mathrm{L}}$ & Torisky et al. 1997 \\
\hline pMP90 & Nopaline-type vir helper plasmid & Koncz and Schell 1986 \\
\hline pAL4404 & Octopine-type vir helper plasmid & Hoekema et al. 1983 \\
\hline pKYRNP1 & Cointegrate of pUCBENP1 with pKYRT1; $\mathrm{Km}^{\mathrm{r}}, \mathrm{Cb}^{\mathrm{r}}$ & This study \\
\hline pKPSNP2 & Cointegrate of pUCBENP1 with pKPSF2; $\mathrm{Em}^{\mathrm{r}}, \mathrm{Km}^{\mathrm{r}}, \mathrm{Cb}^{\mathrm{r}}$ & This study \\
\hline
\end{tabular}


1991; Kovacs and Pueppke 1993). Tumors induced by strains harboring this plasmid produce a set of Amadori-type opines (Chilton et al. 1995; Vaudequin-Dransart et al. 1995) that are conjugates of fructose and glutamine or glutamic acid. pTiChry5 is closely related to the agropine-type Ti plasmid pTiBo542 (Kovacs and Pueppke 1994). However, instead of the Amadori opines, this latter plasmid induces in tumor cells the production of the related mannose conjugates, the mannityl opines (Dessaux et al. 1998).

Given the high degree of tumorigenicity on soybean established by Chry5, Torisky et al. (1997) constructed a disarmed derivative of pTiChry5 called pKYRT1 for use as a vir helper plasmid. However, the vir helper strain KYRT1 maintains very weak oncogenic activity, suggesting that pKYRT1 still harbors one or more T-region border repeats and at least one onc function. In this report, we locate the genes of pTiChry5 required for the synthesis of the Amadori opines to a second, previously unidentified T-region. In the process, we determined the precise locations of both T-regions and their probable flanking border sequences. We show that the vir helper plasmid pKYRT1 harbors one complete T-region as well as the left border repeat of the second and that, when used as a vir helper plasmid in a binary system, this second T-DNA of pKYRT1 is cotransferred to the plant genome at high frequency. Finally, we describe the construction and properties of pKPSF2, an improved vir helper derivative of pTiChry5 that is deleted for all known T-regions and border sequences.

\section{RESULTS AND DISCUSSION}

\section{Mapping a second T-region of pTiChry5 responsible for synthesis of the Amadori opines.}

Tumors induced by Agrobacterium tumefaciens strains harboring pTiChry5 accumulate the Amadori-type opines deoxy- fructosyl glutamine (Dfg) and its lactone, chrysopine (Chy) (Chilton et al. 1995). We localized the genes responsible for the synthesis of these compounds by testing the nopaline-type strain C58 containing a series of overlapping clones from a cosmid library of pTiChry5 for the ability to induce tumors that produce both the arginyl- and Amadori-families of opines. Strains harboring two such clones, $\mathrm{pCH} 235$ and $\mathrm{pCH} 1755$ (Table 1), yielded tumors that produced nopaline and one or more of the Amadori opines (Fig. 1; data not shown). Tumors induced by $\mathrm{C} 58(\mathrm{pCH} 1755)$ produced both Dfg and Chy, while tumors induced by C58(pCH235) contained only Dfg. The inserts in the two clones overlap with each other and cover a region located $25 \mathrm{~kb}$ to the right of the proposed oncogenic Tregion (Fig. 1). Consistent with the report of Kovacs and Pueppke (1994), LBA4404 (Table 1) harboring cosmid clones overlapping the putative oncogenic T-region of pTiChry5 induced tumors (Fig. 1). However, the resulting transformed tissues did not contain detectable amounts of the Amadori opines (Fig. 1; data not shown), which is consistent with our observation that the region of pTiChry 5 responsible for synthesis of these opines maps well to the right of the known oncogenic T-region.

To localize this putative second T-region, we subcloned the segment of DNA corresponding to the region of overlap between cosmid clones pCH1755 and pCH235 into a broadhost-range vector as BamHI or EcoRI fragments and introduced these plasmids into strain C58. Similar to what we observed with pCH235 and pCH1755, EcoRI fragment 5 present in pPOC5E5 conferred synthesis of Dfg but not chrysopine on tumors induced by $\mathrm{C} 58$, while Bam HI fragment 6 present in pPOC5B6 resulted in the synthesis of both Dfg and its lactone (Fig. 1; data not shown). We conclude from these observations that $\mathrm{pCH} 1755$ and pPOC5B6 contain the entire locus for syn-

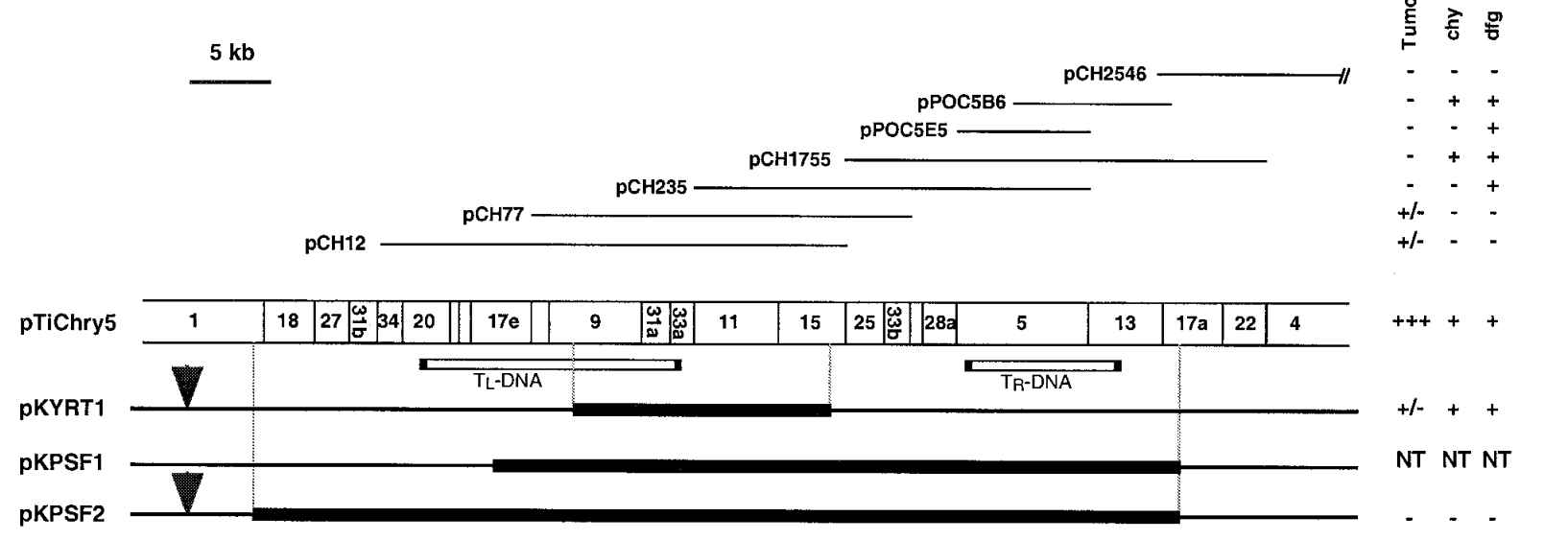

Fig. 1. Organization of the T-regions of pTiChry5. Region of pTiChry5 shown corresponds to coordinates 175 to 47 from the map of Kovacs and Pueppke (1994). Numbered boxes show order of EcoRI fragments in this region. T-regions as identified in this study are represented by open bars, at the ends of which black squares indicate positions of the likely border sequences. Representative cosmid clones and plasmids used to locate the $T_{R}$-DNA are shown above map. Thicker portions of black bars underneath the map represent the extent of DNA deleted in pKYRT1, pKPSF1, and pKPSF2. Vertical arrowheads indicate sites of cointegration of pUCBENP1, which codes for a plant-expressible $n p t I I$ gene, in pKYRT1-K and pKPSF2-K. Tumorigenicity was assayed for each cosmid clone in LBA4404 that contains the vir helper plasmid pAL4404 (Hoekema et al. 1983). Opine production was determined in tumors on tomato plants induced by Chry5, or by the nopaline strain C58 containing one of the appropriate cosmid clones of pTiChry5. Kanamycinresistant $\mathrm{T}_{1}$ seedlings of transgenic Arabidopsis thaliana plants transformed with binary vectors pBIN19 or pBINm-gfp5-ER were analyzed for cotransfer of opine production by the vir helper plasmids pKYRT1 or pKPSF2. 

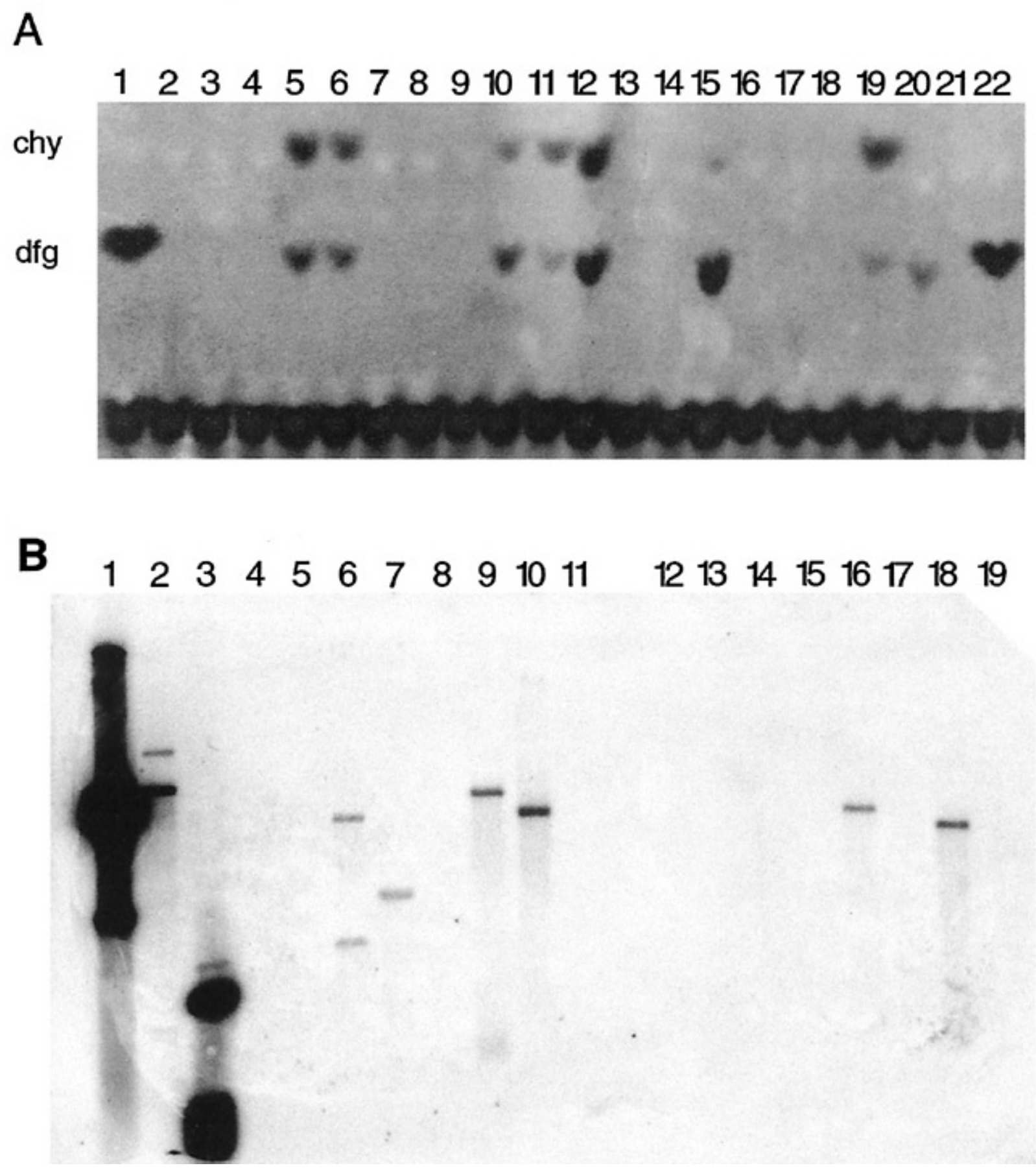

Fig. 2. Opine production and T-DNA presence in Arabidopsis plants transformed by Agrobacterium tumefaciens harboring pKYRT1 as the vir helper plasmid. A. thaliana plants were transformed with Agrobacterium tumefaciens NTL4(pKYRT1) containing binary vector pBINm-gfp5ER. Twenty-one $\mathrm{Km}^{\mathrm{r}} \mathrm{T}_{1}$ plants were selected and $18 \mathrm{~T}_{1}$ plants grew large enough to be assayed for opines. Fourteen lines survived to the $\mathrm{T}_{3}$ generation and were assessed by Southern analysis for the presence of $T_{R}$ DNA from pKYRT1. A, Opine production. Extracts of plants were prepared and subjected to high-voltage paper electrophoresis. The developed electrophoretogram was stained with alkaline silver nitrate to visualize the Amadori opines. Extracts from lanes 1 and 22, wild-type A. thaliana supplemented with $3 \mathrm{mM}$ mannopine; lanes 2 and 21, wildtype A. thaliana; and lanes 3 through $20, \mathrm{Km}^{\mathrm{r}}$ transgenic $\mathrm{T}_{1}$ Arabidopsis lines A-I, K-O, Q-S, and U isolated following transformation by NTL4(pKYRT1, pBINm-gfp5-ER). B, Southern analysis of genomic DNA from transgenic A. thaliana lines. Total genomic DNA from $\mathrm{T}_{3}$ plants, digested with HindIII, was subjected to Southern analysis with as probe a DNA fragment corresponding to the right-hand side of the $\mathrm{T}_{\mathrm{R}}$-DNA of pTiChry5. Lane 1, pPOC5E13; lane 2, pBINm-gfp5-ER + pKYRT1; lane 3, MW marker; lanes 4-16, DNA from lines A-C, E-G, I, $\mathrm{L}, \mathrm{M}, \mathrm{O}, \mathrm{Q}, \mathrm{R}$, and $\mathrm{S}$; and lanes 17 through 19, three segregating lines of the original line $\mathrm{U}$. Lines $\mathrm{D}, \mathrm{H}, \mathrm{K}$, and $\mathrm{N}$ for which opine content is shown in $\mathbf{A}$ did not survive to the $\mathrm{T}_{3}$ generation. 
thesis of the two Amadori opines, while pCH235 and its subclone pPOC5E5 lack the gene or genes necessary for the synthesis of Chy. Furthermore, these results suggest the possibility that chrysopine is synthesized from Dfg. The former opine could be synthesized from Dfg by a pathway similar to the lactonization of mannopine to agropine catalyzed by agropine cyclase. This enzyme is coded for by the $T_{R}$-DNA of octopinetype Ti plasmids (Hong et al. 1997). Consistent with this hypothesis, strain Chry5 produces an enzyme that lactonizes Dfg to Chy (Chilton et al. 1995). Furthermore, since the vectors used in this study do not provide T-region border sequences, at least one border repeat is present on EcoRI fragment 5 of pPOC5E5, while at least one other border repeat must be present on the BamHI fragment of pPOC5B6. Because the region defined by these clones lies well to the right of the known onc T-region (Fig. 1), we conclude from these results that pTiChry5 contains a second T-region harboring at the least the genes for synthesis of the Amadori opines. In this respect, the structure of the T-region of pTiChry5 could be similar to that of pTiBo542. This latter element also contains two T-regions (Hood et al. 1986). The first, $T_{L}$, harbors a set of oncogenes as well as genes for the synthesis of two opine families, succinamopine and agrocinopines $\mathrm{C}$ and $\mathrm{D}$. The second, $\mathrm{T}_{\mathrm{R}}$, harbors a second set of oncogenes as well as the genes for synthesis of the mannityl opines (Hood et al. 1986; P. Oger, V. VaudequinDransart, Y. Dessaux, and S. K. Farrand, in preparation).

\section{The vir helper plasmid pKYRT1 transfers Ti plasmid DNA to plants.}

Given its supervirulent characteristics on soybean, Agrobacterium tumefaciens Chry5 has drawn interest as a tool for genetically engineering recalcitrant plant species. Torisky et al. (1997) reported the construction of a disarmed derivative of pTiChry 5 called pKYRT1 that is deleted for a $16.5-\mathrm{kb}$ segment overlapping the previously described oncogenic T-region (Fig. 1). However, our genetic analysis suggested that pKYRT1 still harbors at least one complete T-region, the $T_{R}$. To determine whether pKYRT1 transfers this second T-DNA to plant cells, we examined derivatives of Arabidopsis thaliana transformed by the binary strain KYRT1(pBINm-gfp5-ER) (Table 1). Twenty-one T1 Arabidopsis transformants selected for resistance to kanamycin encoded by the binary plasmid were examined for coinheritance of other traits. As assessed by fluorescence microscopy, all expressed green fluorescent protein (GFP) positive, consistent with the linkage of the $g f p$ gene with the nptII gene on the binary T-DNA. Of the $18 \mathrm{~T}_{1}$ transformants that grew large enough to be assayed, eight (45\%) produced the Amadori opines (Fig. 2). Furthermore, Southern analysis of genomic DNA from 14 plants that survived to the $\mathrm{T}_{3}$ generation revealed that all clones that tested positive for opine production also contained DNA homologous to the $T_{\mathrm{R}^{-}}$ DNA of pTiChry5. Most of the lines that failed to produce the opines lacked sequences homologous to this T-DNA (Fig. 2). However, two lines, E and G, contain T-DNA but did not produce detectable levels of opines (Fig. 2). No lines were identified that produced opines and lacked sequences homologous to the T-DNA probe. In all cases examined, expression of $g f p$ cosegregated with resistance to $\mathrm{Km}$. However, these two traits segregated independently from opine production (data not shown). In an analysis of opine/T-DNA-positive line U, opine production cosegregated with the presence of DNA sequences homologous with the $\mathrm{T}_{\mathrm{R}}$-DNA probe; segregants that produced opines retained the homologous DNA, while those that had lost the $\mathrm{T}_{\mathrm{R}}$-DNA failed to produce opines (Fig. 2B, lanes 17-19; data not shown). Thus, pKYRT1 transfers $\mathrm{T}_{\mathrm{R}}$-DNA to plants, and this DNA, which is stably integrated into the plant nuclear genome, confers production of the Amadori opines. Moreover, $T_{R}$ is cotransferred with the engineered T-DNA on the binary vectors at high frequency. Given this observation, we do not recommend the use of pKYRT1 as a vir helper plasmid. Furthermore, this set of experiments focused only on the transfer of the $T_{R}$-DNA. Because KYRT1 produces a few, very small, gall-like growths on infected plants (Fig. 1) (Torisky et al. 1997) it remained possible that the transgenic plants also received and integrated a portion of $\mathrm{T}_{\mathrm{L}}$-DNA from borders still retained in pKYRT1. This possibility prompted us to identify and map the border sequences present on pTiChry5.

\section{Location and nucleotide sequence of the border repeats defining the two T-regions of pTiChry5.}

We located the likely borders of $T_{R}$-DNA by sequencing the two fragments contained in pPOC5E13 and pPOC5E5 (Fig. 1). Two sequences we propose as $T_{R} L B$ and $T_{R} R B$ were identified that showed strong similarities to the known $\mathrm{T}$ region borders of other Ti plasmids (Fig. 3). The presence of a known $\mathrm{T}_{\mathrm{R}}$-DNA gene, orf18, just to the right of the left border repeat, and chs, a homolog of the agropine synthase gene, ags (Hong et al. 1997), which could code for chrysopine synthase (P. Oger, V. Vaudequin-Dransart, Y. Dessaux, and S. K. Farrand, in preparation), located just to the left of the right border repeat (Fig. 4), is consistent with our hypothesis that these repeats are the true borders of $T_{R}$. These two border repeats are located at coordinates 26.4 and 34.5 on the standard map of pTiChry5 (Fig. 4) (Kovacs and Pueppke 1994) and delimit an approximately $8-\mathrm{kb}$ T-region that contains the genes required for synthesis of the Amadori opines (Fig. 1).

\begin{tabular}{|c|c|}
\hline Chry $5 \mathrm{~T}_{\mathrm{L}}, \mathrm{LB}$ & \\
\hline Chry5 $\mathrm{T}_{\mathrm{L}} \mathrm{RB}$ & TGGCAGGATATATTgggaTGTCAA \\
\hline Chry5 $\mathrm{T}_{\mathrm{R}} \mathrm{LB}$ & TGGCAGGATATATCgaggTGTAAAA \\
\hline Chry5 $T_{R} R B$ & TGGCAGGATATATgaCggTGTCgt \\
\hline $5955 \mathrm{LB}-\mathrm{L}$ & TGGCAGGATATATTgtggTGTAAAg \\
\hline $\mathrm{RB}-\mathrm{L}$ & CGGCAGGATATATTCaatTGTAAAt \\
\hline $955 \mathrm{LB}-\mathrm{R}$ & TGGCAGGATATATaccgtTGTAAtt \\
\hline $5955 \mathrm{RB}-\mathrm{F}$ & TGGCAGGATATATgCggtTGTAAtt \\
\hline $37 \mathrm{RB}$ & TGaCAGGATATATTggCgGGTAAAC \\
\hline 37 LB & TGGCAGGATATATTg tggTGTAAAC \\
\hline C58 LB & TGGCAGGATATATTg LggTGTAAAC \\
\hline $58 \mathrm{RB}$ & TGaCAGGATATATTggCgGG \\
\hline 4 TL LB & TGGCAGGATATAT \\
\hline $\mathrm{B} 2 / 73 \mathrm{LB}$ & TGGCAGGATATATTggt \\
\hline $32 / 73 \mathrm{RB}$ & TGGCAGGATGTATCagatTGTAgtg \\
\hline & GCAGGATATAT \\
\hline
\end{tabular}

Fig. 3. Nucleotide sequences of the likely T-region borders of pTiChry5 and their relatedness to border sequences from other Ti and Ri plasmids. The borders of $\mathrm{T}_{\mathrm{L}}$ and $\mathrm{T}_{\mathrm{R}}$ of pTiChry5 were located and sequenced, and the sequences were compared with those of other T-region borders in the data bases. Nucleotides in bold represent two core regions strongly conserved among known border sequences. Nucleotides shown in uppercase are predominant at any position; those in lower case are the rare substitutions. In the consensus sequence " $\mathrm{v}$ " represents an A, G, or C; "d" represents an A, G, or T; and "n" represents any nucleotide. 
We located the probable borders of the left T-region by two approaches. First, we used a synthetic oligonucleotide corresponding to the right border sequence of $T_{R}$-DNA from pTiChry5 to probe Southern blots of pTiChry5 DNA. Such analyses of EcoRI-digested pTiChry5 DNA revealed three signals (data not shown). Two of these correspond to the left (EcoRI fragment 5) and right (EcoRI fragment 13) borders of $\mathrm{T}_{\mathrm{R}}$ sequenced as described above. The third signal, located to EcoRI fragment 20, could represent the left border of $\mathrm{T}_{\mathrm{L}}$. This assignment is consistent with the biological data from Kovacs and Pueppke (1994) showing that the $\mathrm{T}_{\mathrm{L}}$-region spans from coordinates 191.6 to 7.6 on the map of pTiChry5. Sequence analysis of EcoRI fragment 20 identified an open reading frame with relatedness to the agrocinopine synthase gene, acs (data not shown), as well as a sequence, that we propose as $\mathrm{T}_{\mathrm{L}}$ LB, with a strong match to known border sequences (Figs. 3 and 4). Furthermore, the sequence of this fragment was nearly identical $(>99 \%)$ to a sequence located at the left end of the $\mathrm{T}_{\mathrm{L}}$-region of pTiBo542 recently determined in our laboratory (P. Oger, C. Reich, G. J. Olsen, and S. K. Farrand, in preparation). However, we were unable to identify any fragments that could code for the right border of the $\mathrm{T}_{\mathrm{L}}$-DNA by Southern analysis. Based on the hypothesis that the $\mathrm{T}_{\mathrm{L}}$-regions of the two Ti plasmids are colinear, we amplified a fragment containing the putative $\mathrm{T}_{\mathrm{L}}$ right border of pTiChry5 by polymerase chain reaction (PCR) with primers designed from the right border region of $\mathrm{T}_{\mathrm{L}}$ from $\mathrm{pTiB}$ 542. Analysis of the single amplicon from this PCR yielded a sequence likely to be the right border of $T_{L}$ (Fig. 3). Mapping data located this sequence to a region approximately $15 \mathrm{~kb}$ to the right of the acs gene (Fig. 1). This places the right border of $\mathrm{T}_{\mathrm{L}}$ approximately $2 \mathrm{~kb}$ to the right of the $6 b$ gene of pTiChry5 (R. Dinkins, unpublished sequence, U88627) (Fig. 4). The sequences of the proposed four T-region borders of pTiChry5 contain the two conserved core regions required by VirD2 for border processing (Fig. 3). However, the likely right borders of the two Tregions are somewhat more diverged from the consensus sequence in the nonconserved regions.

\section{Disarming pTiChry5.}

By our analysis, pKYRT1 still contains all of $T_{R}$ and as much as $9 \mathrm{~kb}$ of $\mathrm{T}_{\mathrm{L}}$, including the left border repeat (Fig. 1). Although the presence of a right border greatly increases the frequency, a left border sequence is sufficient to initiate DNA transfer to plants (Ramanathan and Veluthambi 1995; Van der Graaff et al 1996; Kononov et al 1997). Hence, the presence of a single border sequence on a vir helper plasmid would result in the transfer of unwanted DNA from the plasmid to the plant (see comment by Smith 1998). In the case of pKYRT1, such transfer is supported by our observation of the integration into the plant genome and expression of the opine synthesis genes carried by $\mathrm{T}_{\mathrm{R}}$ (Table 2; Fig. 2). Therefore, we constructed a new disarmed derivative of pTiChry5 that lacks both $\mathrm{T}$ regions and all known border sequences.

The overall strategy, presented in Figure 5, was based upon the isolation of spontaneous deletion derivatives of the $\mathrm{Ti}$ plasmid exploiting the sensitivity to sucrose conferred by the $s a c B$ gene of Bacillus subtilis (Hynes et al. 1989). The $s a c B-$ sacR-nptI cartridge was cloned as a BamHI fragment into the single BamHI site of EcoRI fragment 9 of pTiChry5 (Fig. 1). This construction was marker exchanged into the Ti plasmid, resulting in pMx230 (Fig. 5). This plasmid was isolated from its Chry5 background and electroporated into NTL4 (Table 1) for further manipulations. Because the use of sucrose sensitivity as a selection can lead to the loss of the entire plasmid, an antibiotic resistance determinant was introduced into pMx230 to maintain selection for the Ti plasmid. To do this, a gene cassette coding for resistance to erythromycin (Ery) from pR29 (Table 1) was inserted as a ClaI fragment into a clone of EcoRI fragment 4 from pTiChry5. This fragment corresponds to a region of the Ti plasmid that is required for catabolism of the Amadori opines but is not essential for tumorigenicity ( $P$. Oger, V. Vaudequin-Dransart, Y. Dessaux, and S. K. Farrand, in preparation). The cloning resulted in the removal of several small, internal, Ti plasmid ClaI fragments (Fig. 5). The mutated EcoRI fragment containing the Ery cassette, recloned into pRK415K to form pRKERd4, was marker exchanged into

A 2 chs RB

B

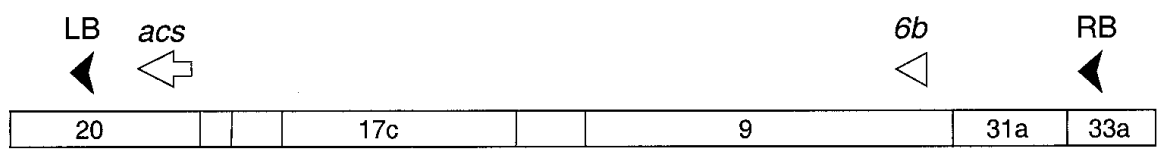

Fig. 4. Fine structure of the two T-regions of pTiChry5. A, Structure of $T_{R}$. B, Structure of $T_{L}$. Locations of open reading frames exhibiting similarity to gene $6 b$, to orf 18 , and to agrocinopine synthase (acs) from several Ti plasmids are shown by open arrows above the EcoRI map. chs represents putative chrysopine synthase gene. Black arrowheads indicate locations of the four probable border sequences that define the two T-regions. 
pMx230 to give pMx106 (Fig. 5). Correct marker exchange events were confirmed by restriction endonuclease analysis and Southern hybridization (data not shown).

Potential deletion derivatives of pMx106 were obtained by selecting for colonies of NTL4(pMx106) able to grow on nutrient agar (NA) supplemented with $5 \%$ sucrose and $150 \mu \mathrm{g}$ of erythromycin per ml. Approximately 100 sucrose-resistant, kanamycin-sensitive colonies were analyzed by DNA restriction analysis. Twenty-four clones with deletions covering both the $T_{L}$ - and $T_{R}$-regions were further characterized by Southern hybridization. These clones fell into two classes: all members of the first set lack both T-regions as well as part of the vir region and are therefore useless as vir helper plasmids. Members of the second set retain vir but still contain part of $\mathrm{T}_{\mathrm{L}}$ and therefore are not completely disarmed. To disarm the plasmid fully, we repeated the selections for sucrose sensitivity starting with pKPSF1, one of the partially disarmed derivatives of pTiChry5 isolated during the first round of screening. This plasmid suffered a deletion that removed the entire $T_{R}$-region, but it still retains approximately $3 \mathrm{~kb}$ of the left end of $\mathrm{T}_{\mathrm{L}}$ (Fig. 1). The sac cassette was marker exchanged into EcoRI fragment 20 of pKPSF1, which contains the likely left border of $T_{L}$, and clones were selected for resistance to sucrose. Of several sucrose-resistant, kanamycin-sensitive clones analyzed, each now lacked this leftmost region of $\mathrm{T}_{\mathrm{L}}$. One clone with a deletion extending from the right end of EcoRI fragment 1 through a portion of EcoRI fragment 17a (Fig. 1) was chosen as a putative fully disarmed derivative and named pKPSF2. According to our mapping data, the deletion in this plasmid removed a segment extending from several kilobases outside of and to the left of the left border of $T_{L}$ to several kilobases outside of and to the right of the right border of $T_{R}$ (Fig. 1). However, the deletion does not extend into the vir region. When tested for virulence on tomato plants, strains harboring pTiChry5 produced large, opine-containing tumors, while KYRT1 produced a few, very small, tumorlike growths (Table 2). A strain harboring pKPSF2 was completely avirulent on this host plant (Table 2).

\section{T-DNA transfer by and vir helper properties of pKPSF2 and pKYRT1.}

We tested the vir helper properties of pKPSF2 by constructing two binary strains, NT1(pKPSF2, pBIN19) and Chry5c(pKYRT1, pBINm-gfp5-ER). A. thaliana was transformed with each strain and progeny resistant to kanamycin were selected and analyzed for coinheritance of other traits. As judged by the appearance of transformants resistant to kanamycin, both vir helper plasmids transferred the binary $\mathrm{T}$ DNA with the same efficiency (Table 3). Furthermore, both transferred the binary T-DNA with an efficiency essentially indistinguishable from that of a standard vir helper plasmid, pMP90, present in GV3101 (Table 3). However, while plants transformed with pKYRT1 coinherited opine production at a high frequency, transformants produced by pKPSF2 did not contain detectable levels of these compounds (Table 3 ).

We also tested for the transfer of unwanted DNA from the vir helper plasmid to the plant cells. To do this, we inserted a plant-selectable marker, nptII, driven by the $35 \mathrm{~S}$ promoter of Cauliflower mosaic virus, into pKPSF2 and pKYRT1 as a whole-vector, Campbell-type cointegrate (Table 1). In each plasmid, the marker was inserted into EcoRI fragment 1 di- rectly counterclockwise from the left edge of the deletion region to create plasmids pKPSF2-K and pKYRT1-K, respectively (Fig. 1). A. thaliana transformed with Agrobacterium tumefaciens strains harboring pKYRT1 or pKPSF2, which do not contain the nptII gene, did not yield kanamycin-resistant transformants at a detectable frequency (Table 3). Similarly, no transformants were obtained from approximately 27,000 seeds tested following infection with NT1(pKPSF2-K). However, infection with Chry5c(pKYRT1-K) yielded five kanamycin-resistant, transgenic plants from about 10,000 seeds plated (Table 3). Although the frequency is low, these results clearly demonstrate that one or more of the border repeats remaining on pKYRT1 can direct transfer of vir helper plasmid DNA to the plant. This transfer occurs in addition to transfer of the $T_{R^{-}}$ DNA also present on this plasmid. On the other hand, our disarmed plasmid, pKPSF2, does not detectably transfer Ti plasmid DNA to the plant. These results are consistent with our mapping data showing that pKPSF2 lacks both T-regions and their associated border sequences. This plasmid therefore constitutes a safe alternative to pKYRT1 for use as a vir helper plasmid.

In conclusion, our analyses indicate that pTiChry5 contains two T-regions. One, $\mathrm{T}_{\mathrm{L}}$, encodes the onc functions and also a gene that could code for the production of the agrocinopinetype opines. The second, $\mathrm{T}_{\mathrm{R}}$, confers production of the Amadori-type opines Dfg and chrysopine. A complete $T_{R}$, as well as the likely left border of $T_{L}$, is retained in pKYRT1, and these borders can and do direct the transfer of pKYRT1 DNA to plant cells when this element is used as a vir helper plasmid. On the other hand, pKPSF2, which is deleted for all known T-regions and their borders, retains vir helper activity but does not detectably transfer Ti plasmid DNA to infected plants.

\section{MATERIALS AND METHODS}

Bacterial strains, plasmids, and growth conditions.

Bacteria and plasmids used in this study are described in Table 1. Strains of Agrobacterium tumefaciens were grown at

Table 2. Tumorigenicity of Agrobacterium tumefaciens harboring pTiChry5 and its deletion derivatives

\begin{tabular}{lcccc}
\hline Plasmid & Characteristics & $\begin{array}{c}\text { Tumorigenicity } \\
\text { on tomato }^{\mathbf{a}}\end{array}$ & \multicolumn{2}{c}{$\begin{array}{c}\text { Amadori opines } \\
\text { in tumors }\end{array}$} \\
\hline $\begin{array}{l}\text { None } \\
\text { pTiChry5 }\end{array}$ & $\begin{array}{c}\text { Wild-type Ti } \\
\text { plasmid }\end{array}$ & - & - & chy \\
pKYRT1 & $\begin{array}{c}\text { Deletion derivative } \\
\text { of pTiChry5 }\end{array}$ & +++ & +++ & +++ \\
pKPSF2 & $\begin{array}{c}\text { Deletion derivative } \\
\text { of pTiChry5 }\end{array}$ & - & $\mathrm{NT}^{\mathrm{d}}$ & $\mathrm{NT}$ \\
\hline
\end{tabular}

${ }^{\mathrm{a}}$ Assessed by inoculating tomato plants with liquid cultures of indicated strain. ++++, Strongly tumorigenic with large, unorganized tumors at all inoculation sites; +/-, very weakly tumorigenic with small growths at a few of the inoculation sites; and -, no tumorous response detected.

${ }^{\mathrm{b}}$ Assessed by high voltage paper electrophoresis of extracts prepared from normal or tumorous tissues.

c Very small, tumorous growths distinguishable from wound callus arose at a few wound sites.

d Not tested. Growths induced by KYRT1 did not yield sufficient tissue for meaningful assays.

e Not applicable. 


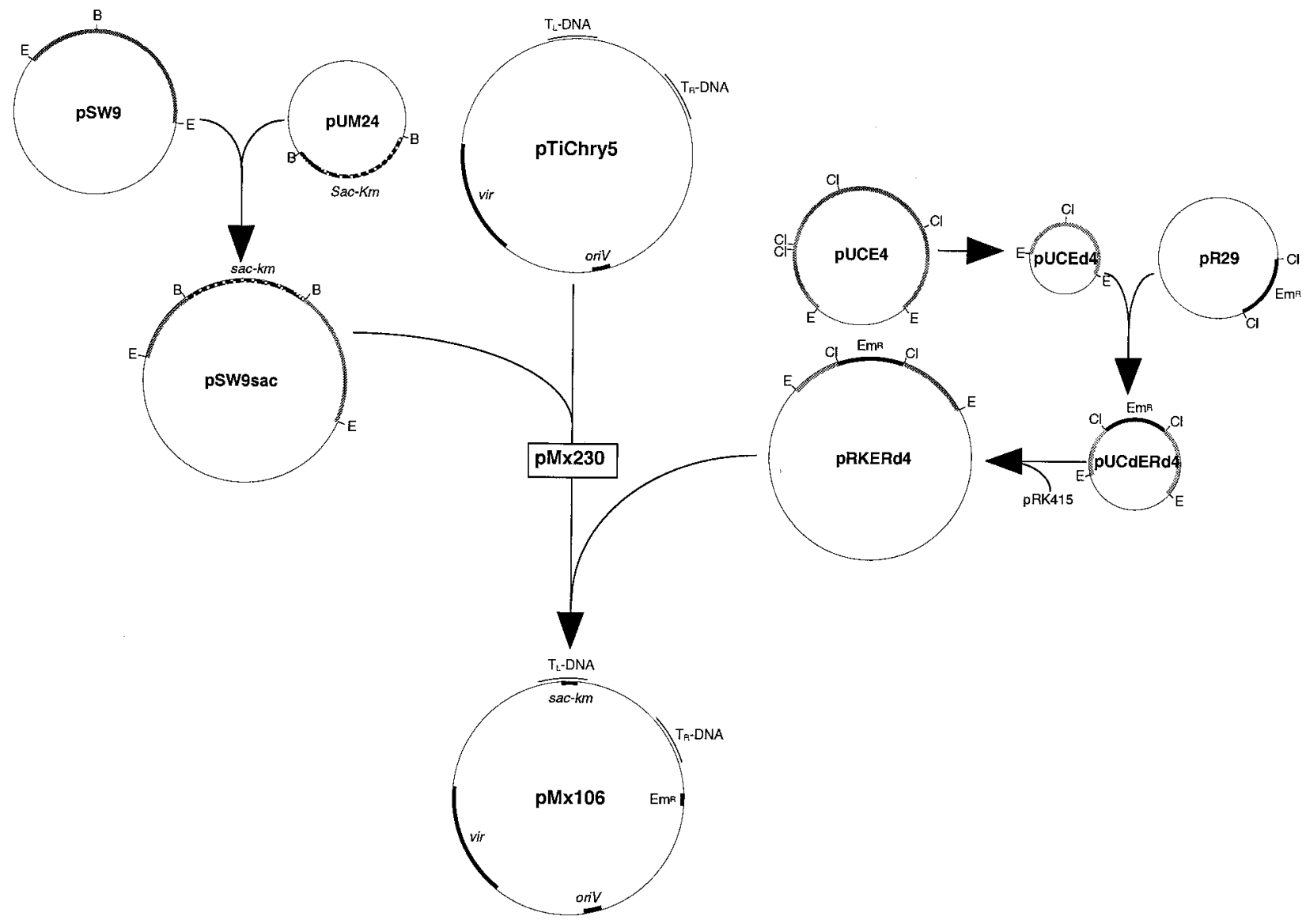

Fig. 5. Strategy for construction of pMx106. The sac-nptI cassette and erythromycin resistance cassette were introduced into pTiChry 5 by two sequential marker exchange events yielding pMx106. This latter plasmid was used to select for deletion derivatives of pTiChry5 culminating in isolation of pKPSF2. Locations of the two T-regions, and the vir region on pTiChry5, as well as the sites of the insertions of the two gene cassettes on pMx106, are indicated. Vectors and intermediate clones are not drawn to scale.

$28^{\circ} \mathrm{C}$ on NA (Difco, Detroit, MI, U.S.A.) and in Luria broth (LB) (Sambrook et al. 1989) or in AB minimal medium (Chilton et al. 1974) with mannitol $(0.25 \%)$ as the carbon source. Strains of Escherichia coli were cultured in LB medium at $37^{\circ} \mathrm{C}$. All media were solidified with $16 \mathrm{~g}$ of Bacto Agar per liter (Difco). Antibiotics were used at the following concentrations in micrograms per milliliter. E. coli: ampicillin (Ap), 100; kanamycin $(\mathrm{Km}), 50$; gentamicin $(\mathrm{Gm}), 30$; erythromycin $(\mathrm{Em})$, 100; and tetracycline (Tc), 10; Agrobacterium tumefaciens: carbenicillin (Cb), 100; Km, 100; Gm, 100; Em, 150; Tc, 2; and rifampicin (Rif), 100. X-gal (5-bromo-4-chloro-3-indolyl$\beta$-D-galactopyranoside) was used at $40 \mu \mathrm{g} / \mathrm{ml}$ when needed.

\section{DNA isolation, marker-exchange mutagenesis, and recombinant DNA techniques.}

Plasmid DNA was isolated from E. coli by the alkaline lysis method described by Sambrook et al. (1989). Ti plasmid DNA and recombinant clones were isolated from Agrobacterium tumefaciens by an alkaline lysis procedure as described by Hayman and Farrand (1990). Plasmids were introduced into Agrobacterium tumefaciens by electroporation (Cangelosi et al. 1991) or by biparental matings with the E. coli strain S17-1 (Cook et al. 1997). Marker exchange of mutated fragments was performed and confirmed as described previously (Farrand et al. 1996).
Total genomic DNA of $A$. thaliana was extracted from 10 to $25 \mathrm{mg}$ of freeze-dried plant tissue after pulverization for $5 \mathrm{~s}$ at speed setting 4.0 in a FastPrep FP120 shaker (Savant Instruments, Farmingdale, NY, U.S.A.), as described by Wang et al. (1994), omitting the cesium chloride purification step.

\section{Nucleotide sequence analysis.}

Complete double-stranded nucleotide sequence determinations were done by the Keck Center (University of Illinois, Urbana, U.S.A.) and by Bio S\&T (Lachine, Québec, Canada). Sequences were assembled and analyzed with Sequencher (Gene Codes, Ann Arbor, MI, U.S.A.). Open reading frames were identified with the Map subroutine of the GCG package (Genetics Computer Group, Madison, WI, U.S.A.) and with DNA Strider (Mark 1988). Sequence comparisons were performed with the BLAST protocols accessible on-line from NCBI. Sequences were deposited in the GenBank data base under the accession numbers AF229155 and AF229156 for the right and left borders of $\mathrm{T}_{\mathrm{L}}$, respectively, and AF229157 for the left and right borders of $T_{R}$.

PCRs.

A fragment containing the right border of $T_{L}$ was amplified from purified pTiChry5 DNA by PCR with the primer set 
Table 3. DNA transmission by and vir helper properties of deletion derivatives of pTiChry5

\begin{tabular}{|c|c|c|c|c|}
\hline $\begin{array}{l}\text { vir Helper } \\
\text { plasmid }\end{array}$ & Characteristics & Binary plasmid & $\begin{array}{l}\text { Fraction of seeds plated } \\
\text { growing on selection plates }\end{array}$ & $\begin{array}{c}\text { Fraction of Km-resistant } \\
\text { plants tested producing } \\
\text { Amadori opines }\end{array}$ \\
\hline pMP90 & Nopaline-type & pBINm-gfp5-ER & 0.0115 & $\mathrm{NT}^{\mathrm{c}}$ \\
\hline \multirow[t]{2}{*}{ pKYRT1 } & Chrysopine-type & None & $<0.00005$ & $\mathrm{NA}^{\mathrm{d}}$ \\
\hline & & pBINm-gfp5-ER & 0.0085 & 0.45 \\
\hline \multirow[t]{2}{*}{ pKPSF2 } & Chrysopine-type & None & $<0.00005$ & NA \\
\hline & & pBIN19 & 0.01 & $<0.05$ \\
\hline pKYRT1-K & Contains a plant-expressible $\mathrm{Km}$ resistance gene & None & 0.0005 & NT \\
\hline pKPSF2-K & Contains a plant-expressible $\mathrm{Km}$ resistance gene & None & $<0.00004$ & NA \\
\hline
\end{tabular}

a Assessed by plating seeds of Arabidopsis thaliana exposed to infection with Agrobacterium tumefaciens harboring indicated plasmids on MurashigeSkoog (MS) medium containing $50 \mu \mathrm{g}$ of kanamycin per ml. Between 10,000 and 27,000 seeds (approximate) were plated on selective media depending on the experiment.

b Assessed by high-voltage paper electrophoretic analysis of extracts prepared from kanamycin-resistant T3 plants. Where available, up to 20 plants were screened from each transformation event.

c Not tested.

${ }^{\mathrm{d}}$ Not applicable.

RBF (5'-AGAGCGTCGTTGGATTCG-3') and RBR (5'CTCCGCACAAGTTACAAAC-3') synthesized by the University of Illinois Keck Center. Conditions for the PCR amplification were as follows. Initial denaturation: $95^{\circ} \mathrm{C}, 3 \mathrm{~min}$. Preamplification cycles: $95^{\circ} \mathrm{C}, 30 \mathrm{~s} ; 50^{\circ} \mathrm{C}, 1 \mathrm{~min} ; 72^{\circ} \mathrm{C}, 2$ min; 5 cycles; amplification: $95^{\circ} \mathrm{C}, 30 \mathrm{~s} ; 58^{\circ} \mathrm{C}, 1 \mathrm{~min} ; 72^{\circ} \mathrm{C}, 2$ min; 30 cycles; final extension: $72^{\circ} \mathrm{C}, 10 \mathrm{~min}$. PCR-generated fragments were purified by agarose gel electrophoresis and sequenced with the amplification primers.

\section{Southern hybridization analysis.}

pTiChry5 and its deletion derivatives were digested to completion with EcoRI. The fragments were separated by electrophoresis through $0.8 \%$ agarose gels, and transferred onto charged nylon membranes (Boehringer-Mannheim, Mannheim, Germany). Probes were prepared from cosmid clones of pTiChry5 (Table 1), including pCH230 ( $\mathrm{T}_{\mathrm{L}}$-region), $\mathrm{pCH} 3701$ (region to the left of $\mathrm{T}_{\mathrm{L}}$ ), and $\mathrm{pCH} 1755$ ( $\mathrm{T}_{\mathrm{R}}$-region), and labeled with the digoxigenin (DIG)-labeling kit from Boehringer-Mannheim as described by the manufacturer. The $\mathrm{T}_{\mathrm{R}}$ right border oligonucleotide $\left(5^{\prime}\right.$ TGGCAGGATATATGACG GTGTCGTG-3'), synthesized by the University of Illinois Keck Center, was end-labeled with the oligonucleotide labeling kit from Boehringer-Mannheim. Southern hybridizations were performed at high stringency in hybridization buffer without formamide at $68^{\circ} \mathrm{C}$ for cosmid probes and at low stringency at $59^{\circ} \mathrm{C}$ when the synthetic border probe was used. Arabidopsis DNA was digested overnight with HindIII. The fragments were separated on $0.8 \%$ agarose gels, and transferred onto charged nylon membranes (Amersham-Pharmacia, Piscataway, NJ). The samples were hybridized with a ${ }^{32} \mathrm{P}$-labeled probe consisting of a 2.07-kb, EcoRI$X m n I$ fragment of pPOC5E13 that contains an internal portion of $\mathrm{T}_{\mathrm{R}}$ from pTiChry5. Hybridizations and washes were conducted under conditions of high stringency as described above.

\section{Plant transformation and tumorigenicity testing.}

Pathogenicity tests were performed on 3-week-old tomato plants grown in the greenhouse. Stems of plants were inoculated with a needle dipped into an overnight culture of the bacterial strain to be tested. Additionally, the cut apex was inoculated with a loopful of bacteria from the same culture. Production of tumors was scored 5 to 6 weeks after inoculation. Transformation of A. thaliana (ecotype Col-0) was accomplished by dipping flowering plants into suspensions of Agrobacterium tumefaciens and selecting transformants from $\mathrm{T}_{1}$ seed spread on plates of MS medium supplemented with $50 \mu \mathrm{g}$ of kanamycin per ml (Clough and Bent 1998).

\section{Analysis for expression of $\boldsymbol{g} f \boldsymbol{p}$.}

Expression of $g f p$ in transgenic A. thaliana plants was assessed by fluorescence microscopy as described by Clough and Bent (1998).

\section{Opine analyses.}

Opines in tomato tumors or in transgenic Arabidopsis plants were detected by high-voltage paper electrophoresis (HVPE) as described by Dessaux et al. (1992). Nopaline was visualized with the phenanthrene quinone reagent (Dessaux et al. 1992), while the Amadori opines were detected with alkaline silver nitrate chemistry (Dessaux et al. 1992). Mannopine (Sigma Chemical, St. Louis, MO, U.S.A.), which also stains with alkaline silver nitrate, electrophoreses with the same mobility as deoxyfructosyl glutamine (Chilton et al. 1995) and was used as the standard in place of this relatively unstable Amadori opine. Chrysopine was the generous gift of W. S. Chilton (North Carolina State University, Raleigh, U.S.A.).

\section{ACKNOWLEDGMENTS}

This work was supported in part by grants NC CNTRL SOY SKF ANTC (S. K. F.) and NC CNTRL SOY AFB ANTC (A. F. B.) from the North Central Soybean Association, and IDA CF 99I-59-4 CS from CFAR to S. K. F. We thank C. Desfeux for critically reading the manuscript.

\section{LITERATURE CITED}

Bevan, M. 1984. Binary Agrobacterium vectors for plant transformation. Nucleic Acids Res. 12:8711-8721.

Binns, A. N., and Costantino, P. 1998. The Agrobacterium oncogenes. Pages 251-266 in: The Rhizobiaceae. Molecular Biology of Model Plant-Associated Bacteria. H. P. Spaink, A. Kondorosi, and P. J. J. Hooykaas, eds. Kluwer Academic Publishers, Dordrecht, The Netherlands.

Bush, A. L., and Pueppke, S. G. 1991. Characterization of a new Agrobacterium tumefaciens strain from Chrysanthemum moriflorum Ram. Appl. Environ. Microbiol. 57:2468-2472.

Cangelosi, G. A., Best, E. A., Martinetti, G., and Nester, E. W. 1991. Genetic analysis of Agrobacterium. Methods Enzymol. 204:384-397.

Chee, P. P., Fober, K. A., and Slightom, J. L. 1989. Transformation of 
soybean (Glycine max) by Agrobacterium tumefaciens. Plant Physiol. 91:1212-1218.

Chen, C. Y., and Winans, S. C. 1991. Controlled expression of the transcriptional activator gene virG in Agrobacterium tumefaciens by using the Escherichia coli lac promoter. J. Bacteriol. 173:1139-1144.

Chilton, M.-D., Currier, T. C., Farrand, S. K., Bendich, A. J., Gordon, M. P., and Nester, E. W. 1974. Agrobacterium tumefaciens DNA and PS8 bacteriophage DNA not detected in crown gall tumors. Proc. Natl. Acad. Sci. U.S.A. 71:3672-3676.

Chilton, W. S., Stomp, A. M., Beringue, V., Bouzar, H., Dransart, V. V., Petit, A., and Dessaux, Y. 1995. The chrysopine family of amadoritype crown gall opines. Phytochemistry 40:619-628.

Clough, S. J., and Bent, A. F. 1998. Floral dip: A simplified method for Agrobacterium-mediated transformation of Arabidopsis thaliana. Plant J. 16:735-743.

Cook, D. M., and Farrand, S. K. 1992. The oriT region of the Agrobacterium tumefaciens Ti plasmid pTiC58 shares DNA sequence identity with the transfer origins of RSF1010 and RK2/RP4 and with T-region borders. J. Bacteriol. 174:6238-6246.

Cook, D. M., Li, P.-L., Ruchaud. F., Padden, S., and Farrand, S. K. 1997. Ti plasmid conjugation is independent of vir: Reconstitution of the tra functions from pTiC58 as a binary system. J. Bacteriol. 179:1291-1297.

de Framond, A. J., Barton, K. A., and Chilton, M.-D. 1983. Mini-Ti: A new vector strategy for plant genetic engineering. Bio/Technology 1 : 262-269.

de la Cruz, F., and Lanka, E. 1998. Function of the Ti-plasmid Vir proteins: T-complex formation and transfer to the plant cell. Pages 281301 in: The Rhizobiaceae. Molecular Biology of Model PlantAssociated Bacteria. H. P. Spaink, A. Kondorosi, and P. J. J. Hooykaas, eds. Kluwer Academic Publishers, Dordrecht, The Netherlands.

Dessaux, Y., Petit, A., Farrand, S. K., and Murphy, P. J. 1998. Opines and opine-like molecules in plant-Rhizobiaceae interactions. Pages 173197 in: The Rhizobiaceae. Molecular Biology of Model Plant-Associated Bacteria. H. P. Spaink, A. Kondorosi, and P. J. J. Hooykaas, eds. Kluwer Academic Publishers, Dordrecht, The Netherlands.

Dessaux, Y., Petit, A., and Tempé, J. 1992. Opines in Agrobacterium biology. Pages 109-136 in: Molecular Signals in Plant-Microbe Communications. D. P. S. Verma, ed. CRC Press, Boca Raton, FL, U.S.A.

Di, R., Purcell, V., Collins, G. B., and Ghabrial, S. A. 1996. Production of transgenic soybean lines expressing the bean pod mottle virus coat protein precursor gene. Plant Cell Rep. 15:746-750.

Farrand, S. K., Hwang, I., and Cook, D. M. 1996. The tra region of the nopaline-type Ti plasmid is a chimera with elements related to the transfer systems of RSF1010, F, and RP4. J. Bacteriol. 178:4233-4247.

Fromm, M. E., Taylor, L. P., and Walbot, V. 1986. Stable transformation of maize after gene transfer by electroporation. Nature (Lond.) 319: 791-793.

Haseloff, J., Siemering, K. R., Prasher, D. C., and Hodge, S. 1997. Removal of a cryptic intron and subcellular localization of green fluorescent protein are required to mark transgenic Arabidopsis plants brightly. Proc. Natl. Acad. Sci. U.S.A. 94:2122-2127.

Hayman, G. T., and Farrand, S. K. 1990. Agrobacterium plasmids encode structurally and functionally different loci for catabolism of agrocinopine-type opines. Mol. Gen. Genet. 223:465-473.

Hinchee, M. A. W., Cannor-Ward, D. V., Newell, C. A., McDonnell, R. E. , Sato, S. J., and Gasser, C. S. 1988. Production of transgenic soybean plants using Agrobacterium-mediated DNA transfer. Bio/Technology 6:915-923.

Hirsch, P. R., and Berenger, J. E. 1984. A physical map of pPH1JI and pJB4JI. Plasmid 12:139-141.

Hoekema, A., Hirsch, P. R., Hooykaas, P. J. J., and Schilperoort, R. A. 1983. A binary plant vector strategy based on separation of the vir and T-region of the Agrobacterium tumefaciens $\mathrm{Ti}$ plasmid. Nature (Lond.) 303:179-180.

Holsters, M., Silva, B., Van Vliet, F., Genetello, C., De Block, M., Dhaese, P., Depicker, A., Inzé, D., Engler, G., Villarroel, R., Van Montagu, M., and Schell, J. 1980. The functional organization of the nopaline $A$. tumefaciens plasmid pTiC58. Plasmid 3:212-230.

Hong, S.-B., Hwang, I., Dessaux, Y., Guyon, P., Kim, K.-S., and Farrand, S. K. 1997. A T-DNA gene required for agropine biosynthesis by transformed plants is functionally and evolutionarily related to a $\mathrm{Ti}$ plasmid gene required for catabolism of agropine by Agrobacterium strains. J. Bacteriol. 179:4831-4840.

Hood, E. E., Chilton, W. S., Chilton, M.-D., and Fraley, R. T. 1986. T-
DNA and opine synthetic loci in tumors incited by Agrobacterium tumefaciens A281 on soybean and alfalfa plants. J. Bacteriol. 168:12831290.

Hood, E. E., Gelvin, S. B., Melchers, L. S., and Hoekema, A. 1993. New Agrobacterium helper plasmids for gene transfer to plants. Transgen. Res. 2:208-218.

Hooykaas, P. J. J., and Schilperoort, R. A. 1992. Agrobacterium and plant genetic engineering. Plant Mol. Biol. 19:15-38.

Hynes, M. F., Quandt, J., O'Connell, M. P., and Pühler, A. 1989. Direct selection for curing and deletion of Rhizobium plasmids using transposons carrying the Bacillus subtilis sacB gene. Gene 78:111-120.

Jones, J. D. G., Shlumukov, L., Carland, F., English, J., Scofield, S. R., Bishop, G. J., and Harrison, K. 1992. Effective vectors for transformation, expression of heterologous genes, and assaying transposon excision in transgenic plants. Transgen. Res. 1:285-297.

Koncz, C., and Schell, J. 1986. The promoter of the $\mathrm{T}_{\mathrm{L}}$-DNA gene 5 controls the tissue-specific expression of chimeric genes carried by a novel type of Agrobacterium binary vector. Mol. Gen. Genet. 204: 383-396.

Kononov, M. E., Bassuner, B., and Gelvin, S. B. 1997. Integration of TDNA binary vector 'backbone' sequences into the tobacco genome; Evidence for multiple complex patterns of integration. Plant J. 11: 945-957.

Kovach, M. E., Elzer, P. H., Hill, D. S., Robertson, G. T., Farris, M. A., Roop, R. M., II, and Peterson, K. M. 1995. Four new derivatives of the broad-host-range cloning vector pBBR1MCS, carrying different antibiotic-resistance cassettes. Gene 166:175-176.

Kovacs, L. G., and Pueppke, S. G. 1993. The chromosomal background of Agrobacterium tumefaciens Chry5 conditions high virulence on soybean. Mol. Gen. Genet. 6:601-608.

Kovacs, L. G., and Pueppke, S. G. 1994. Mapping and genetic organization of pTiChry5, a novel Ti plasmid from a highly virulent Agrobacterium tumefaciens strain. Mol. Gen. Genet. 242:327-336.

Mark, C. 1988 "DNA Strider": A "C" program for the fast analysis of DNA and protein sequences on the Apple Macintosh family of computers. Nucleic Acids Res. 16:1829-1836.

McCabe, D. E., Swain, W. F., Martinell, B. J., and Christou, P. 1988 Stable transformation of soybean (Glycine max) by particle acceleration. Bio/Technology 6:923-926.

Meurer, C. A., Dinkins, R. D., and Collins, G. B. 1998. Factors affecting soybean cotyledonary node transformation. Plant Cell Rep. 18:180-186.

Morrison, D. A., Trombe, M.-C., Hayden, M. K., Waszak, G. A., and Chen, J. D. 1984. Isolation of transformation-deficient Streptococcus pneumoniae mutants defective in control of competence, using insertion-duplication mutagenesis with the erythromycin resistance determinant of pAMb1. J. Bacteriol. 159:870-876.

Peralta, E. G., and Ream, L. W. 1985. T-DNA border sequences required for crown gall tumorigenesis. Proc. Natl. Acad. Sci. U.S.A. 82:51125116.

Ramanathan, V., and Veluthambi, K. 1995. Transfer of non T-DNA portions of the Agrobacterium tumefaciens Ti plasmid pTiA6 from the left terminus of $\mathrm{T}_{\mathrm{L}}$-DNA. Plant Mol. Biol. 28:1149-1154.

Ried, J. L., and Collmer, A. 1987. An nptI-sacB-sacR cartridge for constructing directed, unmarked mutations in Gram-negative bacteria by marker exchange-eviction mutagenesis. Gene 57:239-246.

Sambrook, J., Fritsch, E. F., and Maniatis, T. 1989. Molecular Cloning: A Laboratory Manual. 2nd ed. Cold Spring Harbor Laboratory, Cold Spring Harbor, NY, U.S.A.

Simon, R., Priefer, U., and Pühler, A. 1983. A broad host range mobilization system for in vivo genetic engineering: Transposon mutagenesis in gram-negative bacteria. Bio/Technology 1:784-791.

Smith, N. 1998. More T-DNA than meets the eye. Trends Plant Sci. 3:85.

Torisky, R. S., Kovacs, L., Avdiushko, S., Newman, J. D., Hunt, A. G., and Collins, G. B. 1997. Development of a binary vector system for plant transformation based on the supervirulent Agrobacterium tumefaciens strain Chry5. Plant Cell Rep. 17:102-108.

Trick, H. N., and Finer, J. J. 1997. SAAT: Sonication-assisted Agrobacterium transformation. Transgen. Res. 6:329-334.

Van der Graaff, E., den Dulk Ras, A., and Hooykaas, P. J. J. 1996. Deviating T-DNA transfer from Agrobacterium tumefaciens to plants. Plant Mol. Biol. 31:677-681.

Vaudequin-Dransart, V., Petit, A., Poncet, C., Ponsonnet, C., Nesme, X., Jones, J. B., Bouzar, H., Chilton, W. S., and Dessaux, Y. 1995. Novel Ti plasmids in Agrobacterium strains isolated from fig tree and chry- 
santhemum tumors and their opinelike molecules. Mol. Plant-Microbe Interact. 8:311-321.

Wang, C. S., Todd, J. J., and Vodkin, L. O. 1994. Chalcone synthase mRNA and activity are reduced in yellow soybean seed coats and dominant I alleles. Plant Physiol. 105:739-748.

Wang, K., Herrera-Estrella, L., Montagu, V. M., and Zambryski, P. 1984. Right 25 bp terminus sequences of the nopaline T-DNA is essential for and determines direction of DNA transfer from Agrobacterium to the plant genome. Cell 38:455-462.

Yadav, N. S., Vanderleyden, J., Bennett, D., Barnes, W. J., and Chilton, M.-D. 1982. Short direct repeats flank the T-DNA on a nopaline Ti plasmid. Proc. Natl. Acad. Sci. U.S.A. 79:6322-6326.

Zambryski, P., Depicker, A., Kruger, K., and Goodman, H. M. 1982. Tumor induction by Agrobacterium tumefaciens: Analysis of the boundaries of T-DNA. J. Mol. Appl. Genet. 1:361-370.

Zambryski, P., Joos, H., Genetello, C., Leemans, J., van Montagu, M., and Schell, J. 1983. Ti plasmid vector for the introduction of DNA into plant cells without alteration of their normal regeneration capacity. EMBO J. 4:3069-3076.

Zupan, J. R., and Zambryski, P. 1995. Update on plant transformation: Transfer of T-DNA from Agrobacterium to the plant cell. Plant Physiol. 107:1041-1047. 